\title{
ANALISIS PENENTUAN HARGA POKOK PRODUKSI UNTUK MENENTUKAN HARGA JUAL PADA UMKM DI KOTA TEGAL
}

\author{
Hetika \\ Politeknik Harapan Bersama \\ hetika.maksi@gmail.com \\ Yeni Priatna Sari \\ Politeknik Harapan Bersaa \\ yenipriatna@gmail.com
}

\begin{abstract}
The selling price is the amount of the price that will be set to the consumer which is obtained or calculated from the production cost plus the expected non-production and profit costs. Determining the selling price is important determines the sustainability of the business. In calculating the cost of production of information needed by SMEs is information about raw materials, labor costs and factory overhead costs. There are several approaches that can be used to determine the cost of production, namely the full costing and variable costing methods. The purpose of this research is to find out the method of determining the right cost of production to determine the selling price of the product. Data collection methods in this study use observation methods and direct interviews with respondents. This study uses descriptive analysis techniques to determine the determination of the cost of production on SMEs in Tegal City. The results show that the full costing method is more appropriate to be used as a consideration in determining the selling price compared to the variable costing method. The full costing method is also more easily understood by SMEs compared to the variable costing method because SMEs are still having difficulty identifying fixed and variable factory overhead costs.
\end{abstract}

Keywords: cost of production, SMEs

\section{PENDAHULUAN}

Harga jual merupakan besarnya harga yang akan ditetapkan kepada konsumen yang diperoleh atau dihitung dari biaya produksi ditambah dengan biaya non produksi dan laba yang diharapkan (Mulyadi, 2010) Penentuan harga jual merupakan hal penting. Bagi sektor usaha yang sudah berpengalaman, penetapan harga jual mungkin bukan hal yang sulit, namun bagi pelaku usaha yang belum lama menekuni dunia usaha penentuan harga jual merupakan hal yang menyulitkan. Penentuan harga jual akan berpengaruh pada keputusan pembelian konsumen. Apabila penentuan harga jual terlalu tinggi maka konsumen tidak akan membeli barang yang ditawarkan, namun jika penetapan harga jual terlalu rendah maka pemilik usaha akan sulit untuk mencari keuntungan. Oleh karena itu, penetapan harga 
jual merupakan salah satu faktor penting bagi pemilik usaha.

Seperti usaha pada umumnya, Usaha Mikro, Kecil dan Menengah (UMKM) memiliki tujuan untuk mencari keuntungan. Sehingga penentuan harga jual merupakan hal penting dan menentukan keberlangsungan usaha. Penentapan harga jual merupakan salah satu komponen dalam strategi pemasaran produk dimana dalam menentukan harga jual perusahaan harus mempertimbangkan beberapa hal yaitu kalkulasi biaya. Pada sector usaha yang bergerak di bidang produksi, biaya produksi atau harga pokok produksi merupakan komponen yang berpengaruh pada penentuan harga jual. Penentuan harga pokok produksi harus tepat dan akurat agar menunjukkan harga pokok yang sesungguhnya.

Dalam perhitungan harga pokok produksi informasi yang diperlukan UMKM adalah informasi mengenai bahan baku, biaya tenaga kerja dan biaya overhead pabrik. Sedangkan berdasarkan hasil wawancara dengan pelaku UMKM di Kota Tegal yang menjadi anggota kelompok Mitra UMKM Prodi Akuntansi Politeknik Harapan Bersama diperoleh informasi bahwa para pelaku UMKM yang bergerak di bidang produksi mengalami kesulitan dalam menentukan harga pokok produksi, sehingga penetapan harga jual dan laba yang diharapkan dikhawatirkan kurang akurat.

Terdapat beberapa pendekatan yang dapat digunakan untuk menentukan harga pokok produksi yaitu metode full costing dan variable costing. Metode full costing merupakan metode penentuan harga pokok produksi yang mengitung semua unsur biaya bahan baku, biaya tenaga kerja langsung dan biaya overhead pabrik yang berlaku variable maupun tetap. Sedangkan metode variable costing merupakan metode penentuan harga pokok produksi yang hanya menghitung biaya produksi yang berperilaku variable ke dalam harga pokok produksi yang terdiri dari biaya bahan baku, biaya tenaga kerja langsung dan biaya overhead pabrik variable. Hasil perhitungan dengan kedua metode tersebut dapat menghasilkan harga pokok produksi yang berbeda. Penelitian ini dilakukan untuk menevaluasi penentuan harga pokok produksi yang tepat untuk menentukan harga jual produk.

\section{TINJAUAN PUSTAKA}

\section{Harga Jual}

Hansen dan Mowen (2005) menyatakan bahwa harga jual adalah jumlah moeter yang dibebankan oleh suatu unit usaha kepada pembeli atau pelanggan atas barang atau jasa yang dijual atau diserahkan. Sedangkan 
menurut Sukirno (2006) ${ }^{[3]}$ harga jual adalah harga yang ditentukan untuk sebuah produk yang dapat mempengaruhi pendapatan perusahaan dan laba yang diinginkan. Pendapat lainnya menjelaskan bahwa harga jual adalah besarnya harga yang akan ditetapkan kepada konsumen yang diperoleh atau dihitung dari biaya produksi ditambah dengan biaya non produksi dan laba yang diharapkan (Mulyadi, 2010) Berdasarkan beberapa pendapat di atas dapat dipahami bahwa sejumlah unit moneter yang dapat dibebankan oleh pemilik usaha untuk sebuah produk yang dipasarkan.

\section{Harga Pokok Produksi}

Harga pokok produksi merupakan elemen penting bagi perusahaan manufaktur. Harga pokok produksi pada dasarnya mennjukkan harga pokok dari suatu produk yang dihasilkan dalam suatu periode akuntansi tertentu. Menurut Mulyadi (2010) harga pokok produksii atau product cost merupakan elemen penting untuk menilai suatu keberhasilan (performance) dari perusahaan dagang maupun manufaktur. Harga pokok produksi berkaitan erat dengan indicator-inikator tentang sukses perusahaan seperti laba kotor atau laba bersih penjualan.

Biaya-biaya dalam penentuan harga pokok produksi terdiri dari tiga unsur, yaitu:

1. Biaya Bahan Baku
Biaya bahan baku adalah biaya bahan yang dipakai untuk diolah menjadi bahan produk jadi.

\section{Biaya Tenaga Kerja}

Biaya tenaga kerja merupakan balas jasa yang diberikan kepada karyawan produksi baik yang secara langsung maupun yang tidak langsung turut ikut mengerjakan produksi barang yang bersangkutan. Biaya tenaga kerja terdiri dari:

a. Biaya tenaga kerja langsung, yaitu balas jasa yang diberikan oleh perusahaan kepada tenaga kerja langsung dan manfaatnya dapat diidentifikasikan pada produk tertentu.

b. Biaya tenaga kerja tidak langsung meliputi semua biaya (gaji dan upah) tenaga kerja bagian produksi yang terlibat langsung dalam proses pengerjaan bahan baku.

3. Biaya Overhead Pabrik

Biaya overhead pabrik merupakan biaya yang tidak dapat dibebankan secara langsung pada suatu hasil produk.

Terdapat beberapa pendekatan dalam menentukan harga pokok produksi:

1. Metode Full Costing

Merupakan metode penentuan harga pokok produksi yang menghitung semua unsur biaya bahan baku, biaya tenaga kerja 
langsung, dan biaya overhead pabrik yang berlaku variable maupun tetap.

2. Metode Variable Costing

Merupakan metode penentuan harga pokok produksi yang hanya menghitung biaya produksi yang berperilaku variable ke dalam harga pokok produksi yang terdiri dari biaya bahan baku, biaya tenaga kerja langsung, dan biaya overhead pabrik variable.

\section{Manfaat Informasi Harga Pokok Produksi}

Pada dasarnya tujuan penentuan harga pokok produksi adalah untuk menentukan secara tepat jumlah biaya perunit produk jadi, sehingga dapat diketahui laba atau rugi suatu perusahaan per periode. Menurut Mulyadi (2010) manfaat dari penentuan harga pokok produksi secara garis besar adalah sebagai berikut:

1. Menentukan Harga Jual Produk Perusahaan yang berproduksi massal memproses produknya untuk memenuhi persediaan di gudang dengan demikian biaya produksi dihitung untuk jangka waktu tertentu untuk menghasilkan informasi biaya produksi per satuan produk. Penentuan harga jual produk, biaya produksi per unit merupakan salah satu data yang dipertimbangkan disamping data biaya lain serta data non biaya.
2. Memantau Realisasi Biaya Produksi Manajemen memerlukan informasi biaya produksi yang sesungguhnya dikeluarkan dibandingkan dengan rencana produksi yang telah ditetapkan, oleh sebab itu akuntansi biaya digunakan dalam jangka waktu tertentu untuk memantau apakah produksi mengkonsumsi total biaya produksi sesuai dengan yang diperhitungkan sebelumnya.

3. Menghitung Laba Rugi Periodik

Guna mengetahui apakah kegiatan produksi dan pemasaran perusahaan dalam periode tertentu mampu menghasilkan laba bruto. Manajemen memerlukan ketepatan penentuan laba periodik, sedangkan laba periodik yang tepat harus berdasarkan informasi biaya dan penentuan biaya yang tepat pula.

4. Menentukan Harga Pokok Persediaan Produk Jadi dan Produk Dalam Proses yang Disajikan dalam Neraca.

Saat manajemen dituntut untuk membuat pertanggungjawaban perperiode, manajemen harus menyajikan laporan keuangan berupa neraca dan laporan laba rugi yang menyajikan harga pokok persediaan produk jadi dan harga pokok yang pada tanggal neraca masih dalam proses. Berdasarkan catatan biaya produksi yang masih melekat pada produk jadi yang 
belum di jual pada tanggal neraca serta dapat diketahui biaya produksinya. Biaya yang melekat pada produk jadi pada tanggal neraca disajikan dalam harga pokok persediaan produk jadi. Biaya produksi yang melekat pada produk yang pada tanggal neraca masih dalam proses pengerjaan disajikan dalam neraca sebagai harga pokok persediaan produk ke dalam proses.

\section{Usaha Mikro, Kecil dan Menengah} (UMKM)

Berikut ini merupakan definisi Usaha Mikro, Kecil dan Menengah (UMKM) menurut Undang-Undang Republik Indonesia Nomor 20 Tahun 2008:

1. Usaha Mikro adalah usaha produktif milik orang perorangan dan/atau badan usaha perorangan yang memnuhi kriteria Usaha Mikro.

2. Usaha Kecil adalah usaha ekonomi produktif yang berdiri sendiri, yang dilakukan oleh orang perorangan atau badan usaha yang bukan merupakan anak perusahan atau bukan cabang perusahaan yang dimiliki, dikuasai atau menjadi bagian baik langsung maupun tidak langsung dari Usaha Menengah atau Usaha Besar yang memenuhi kriteria Usaha Kecil.
3. Usaha Menengah adalah usaha ekonomi produktif yang berdiri sendiri yang dilakukan oleh orang perorangan atau badan usaha yang bukan merupakan adak perusahaan atau cabang perusahaan yang dimiliki, dikuasai atau menjadi bagian baik langsung maupun tidak langsung dengan Usaha Kecil atau Besar dengan jumlah kekayaan bersih atau hasil penjualan tahunan.

Kriteria Usaha Mikro, Kecil dan Menengah (UMKM) menurut UU Nomor 20 tahun 2008 adalah sebagai berikut:

1. Kriteria Usaha Mikro

a. Kekayaan bersih paling banyak $\mathrm{Rp}$ 50.000.000,00 - lima puluh juta rupiah, tidak termasuk tanah dan bangunan tempat usaha; atau

b. Hasil penjualan tahunan paling banyak Rp 300.000.000,00

2. Kriteria Usaha Kecil

a. Memiliki kekayaan bersih lebih dari Rp 50.000.000,00 - $\quad \mathrm{Rp}$ 500.000.000,00, tidak termasuk tanah dan bangunan tempat usaha; atau

b. Memiliki hasil penjualan tahunan lebih dari Rp 300.000.000,00 - Rp 2.500.000.000,00.

3. Kriteria Usaha Menengah

a. Kekayaan bersih lebih dari Rp 500.000.000,00 - $\quad$ Rp. 
10.000.000.000,00, tidak termasuk tanah dan bangunan tempat usaha; atau

b. Hasil penjualan tahunan lebih dari $\mathrm{Rp}$ 2.500.000.000,00 -50.000.000.000,00.

\section{METODE PENELITIAN}

\section{Populasi dan Sampel}

Penelitian ini merupakan penelitian lnjutan, dimana hasil penelitian sebelumnya menunjukkan bahwa para pelaku UMKM kesulitan dalam menentukan harga pokok produksi yang tepat untuk menentukan harga jual yang akurat. Para pelaku UMKM mayoritasi mayoritas menggunakan perkiraan dalam menentukan harga pokok produksi sehingga dikhawatirkan keliru ketika menentukan harga jual.

Populasi dalam penelitian ini adalah UMKM yang bergerak di sector industri di Kota Tegal, berjumlah sekitar 30.000 unit (Dinas Perindag, Koperasi dan UKM Kota Tegal, 2016). Melihat banyaknya UMKM di Kota Tegal serta keterbatasan peneliti, maka peneliti mengambil sampel penelitian dengan teknik purposive sample yaitu merupakan teknik pengambilan sampel berdasarkan pertimbangan-pertimbangan tertentu sesuai dengan tujuan penelitian (Sugiyono, 2014) ${ }^{[4]}$.
Adapun kriteria dalam pengambilan sampel adalah sebagai berikut:

1. UMKM yang tergabung dalam kelompok UMKM binaan Program Studi D III Akuntansi Politeknik Harapan Bersama.

2. UMKM yang melakukan kegiatan penjualan secara berkelanjutan.

3. UMKM yang memiliki omset Rp1,000,000-Rp25,000,000 per bulan.

4. UMKM yang telah melakukan pengumpulan bukti transaksi.

5. UMKM yang bergerak di bidang produksi.

Berdasarkan kriteria pengambilan sampel di atas diperoleh jumlah sampel dalam penelitian ini adalah sebanyak 4 UMKM. Teknik ini dilakukan karena keterbatasan waktu, tenaga, dan dana sehingga tidak dapat mengambil sampel yang besar dan jauh.

\section{Metode Pengumpulan Data}

Penelitian ini merupakan penelitian lapangan (field research), dalam pengumpulan data atau informasi yang dibutuhkan dalam penelitian adalah melalui wawancara dan observasi yaitu dengan cara peninjauan langsung pada objek penelitian guna mendapatkan data dan informasi yang akurat terkait dengan penyusunan laporan keuangan UMKM.

\section{Teknik Analisis Data}

Penelitian ini merupakan penelitian deskriptif dengan menggunakan pendekatan 
kualitatif dan kuantitatif untuk memberikan ulasan yang diperoleh Pendekatan penelitian deskriptif dalam penelitian ini hanya sebatas membuat deskripsi tentang fenomena di lapangan sedangkan pendekatan kuantitatif dalam penelitian ini digunakan untuk membuat deskripsi tentang penentuan harga pokok produksi dengan pendekatan full costing dan variable costing.

\section{HASIL PENELITIAN}

Penelitian ini dilakukan untuk mengetahui metode penentuan harga pokok produksi yang tepat untuk menentukan harga jual produk. Hal ini disebabkan karena masih banyak UMKM di Kota Tegal yang mengalami kesulitan dalam menentukan harga pokok produksi, sehingga penetapan harga jual dan laba yang diharapkan dikhawatirkan kurang akurat. Berdasarkan hasil penelitian, kendala yang selama ini dihadapi pelaku UMKM dalam menentukan harga pokok produksi adalah (1) keterbatasan kemampuan dan ilmu pengetahuan di bidang akuntansi (2) tidak adanya tenaga ahli di bidang akuntansi (3) bagi UMKM yang pernah mendapatkan pelatihan akuntansi, merasa bahwa akuntansi terlalu rumit, (4) waktu yang habis terbuang untuk mengawasi proses produksi yang dilakukan oleh karyawan sehingga sulit menyisihkan waktu untuk mencatat semua transaksi pemasukan dan pengeluaran yang dilakukan dalam proses produksi.

Hasil penelitian menunjukkan bahwa sebagian besar UMKM binaan Program Studi DIII Akuntansi Politeknik Harapan Bersama bergerak di bidang produksi tidak melakukan perhitungan harga pokok produksi secara detail ketika menentukan harga jual. Dasar penentuan harga jual yang selama ini digunakan hanya dengan pertimbangan pemilik UMKM dan melihat harga pasaran.

Hasil penelitian menunjukkan bahwa sebagian besar UMKM yang bergerak di bidang produksi belum secara detail memperhitungkan harga pokok produksi dalam menentukan harga jual, sehingga tidak bisa diketahui secara pasti biaya produksi yang dikeluarkan untuk produk yang dihasilkan. Berikut ini merupakan hasil perhitungan harga pokok produksi pada UMKM yang menjadi responden dalam penelitian ini:

\section{Perhitungan Harga Pokok Produksi Kreafure Sofa}

Berdasarkan hasil penelitian, untuk memproduksi sofa dibutuhkan biaya bahan baku, biaya tenaga kerja langsung dan biaya overhead pabrik, meliputi:

a. Bahan baku: kayu pinus sebagai kerangka sofa, karet ban, kain oscar, kaca, dan kaki penyangga. 
b. Biaya tenaga kerja langsung adalah biaya yang dikeluarkan untuk membayar tenaga kerja yang berperan dalam proses produksi. Biaya tenaga kerja langsung disini meliputi biaya perakitan sofa langsung, dan biaya pemotongan kayu langsung.

c. Biaya overhead pabrik meliputi biaya overhead pabrik tetap, dan biaya overhead pabrik variabel. BOP Tetap dalam proses ini adalah kardus, per pegas, lem aibo dan steples tembak. Sedangkan BOP Variabelnya adalah listrik untuk produksi.

Berikut ini merupakan perbandingan perhitungan komponen harga pokok produksi menggunakan metode full costing dan metode variabel costing untuk memproduksi satu unit sofa:

\section{Tabel 4.1}

\section{Perhitungan Komponen Harga Pokok}

\section{Produksi Kreafure Sofa}

\begin{tabular}{|l|ll|ll|}
\hline Komponen Biaya & \multicolumn{2}{|c|}{$\begin{array}{c}\text { Metode Full } \\
\text { Costing }\end{array}$} & \multicolumn{2}{|c|}{$\begin{array}{c}\text { Metode Variable } \\
\text { Costing }\end{array}$} \\
\hline $\begin{array}{l}\text { Biaya Bahan } \\
\text { Baku }\end{array}$ & \multicolumn{2}{|l|}{} & \multicolumn{2}{|l|}{} \\
\hline Kayu Pinus & $\mathrm{Rp}$ & 900.000 & $\mathrm{Rp}$ & 900.000 \\
\hline Karet Ban & $\mathrm{Rp}$ & 100.000 & $\mathrm{Rp}$ & 100.000 \\
\hline Busa & $\mathrm{Rp}$ & 800.000 & $\mathrm{Rp}$ & 800.000 \\
\hline Kain Oscar & $\mathrm{Rp}$ & 540.000 & $\mathrm{Rp}$ & 540.000 \\
\hline Kaca & $\mathrm{Rp}$ & 150.000 & $\mathrm{Rp}$ & 150.000 \\
\hline Kaki penyangga & $\mathrm{Rp}$ & 20.000 & $\mathrm{Rp}$ & 20.000 \\
\hline $\begin{array}{l}\text { Biaya Tenaga } \\
\text { Kerja }\end{array}$ & \multicolumn{2}{|l|}{} & \multicolumn{2}{|l|}{} \\
\hline
\end{tabular}

\begin{tabular}{|c|c|c|c|c|}
\hline Komponen Biaya & \multicolumn{2}{|c|}{$\begin{array}{c}\text { Metode Full } \\
\text { Coctina }\end{array}$} & \multicolumn{2}{|c|}{$\begin{array}{c}\text { Metode Variable } \\
\text { Coctins }\end{array}$} \\
\hline $\begin{array}{l}\text { Karyawan perakit } \\
\text { sofa }\end{array}$ & $\mathrm{Rp}$ & 250.000 & $\mathrm{Rp}$ & 250.000 \\
\hline $\begin{array}{l}\text { Karyawan } \\
\text { pemotong kayu }\end{array}$ & $\mathrm{Rp}$ & 60.000 & $\mathrm{Rp}$ & 60.000 \\
\hline \multicolumn{5}{|l|}{$\begin{array}{l}\text { Biaya Overhead } \\
\text { Pabrik }\end{array}$} \\
\hline \multicolumn{5}{|l|}{ BOP Tetap: } \\
\hline Kardus & $\mathrm{Rp}$ & 10.000 & & \\
\hline Per pegas & $\mathrm{Rp}$ & 30.000 & & \\
\hline Lem aibon & $\mathrm{Rp}$ & 32.000 & & \\
\hline Steples tembak & $\mathrm{Rp}$ & 80.000 & & \\
\hline \multicolumn{5}{|l|}{ BOP Variabel: } \\
\hline $\begin{array}{l}\text { Listrik untuk } \\
\text { produksi }\end{array}$ & $\mathrm{Rp}$ & 50.000 & $\mathrm{Rp}$ & 50.000 \\
\hline Total HPP & $\mathbf{R p}$ & 3.022 .000 & $\mathbf{R p}$ & 2.870 .000 \\
\hline
\end{tabular}

Sumber: Data Primer diolah tahun 2018

Berdasarkan hasil perhitungan pada tabel 4.1 di atas terdapat perbedaan Harga Pokok Produksi sofa antara metode full costing dengan metode variable costing, selisihnya sebesar Rp 152.000. Selisih tersebut terjadi karena pada metode variable costing tidak memperhitungkan elemen biaya overhead pabrik tetap. Jika para pelaku UMKM menggunakan perhitungan harga pokok produksi sebagai pertimbangan dalam menentukan harga jual, maka metode full costing lebih tepat digunakan, karena jika para pelaku UMKM mengunakan metode variable costing maka ada elemen biaya yang tidak diperhitungkan sehingga dikhawatirkan para pelaku UMKM akan mengalami kerugian karena tidak membebankan beberapa elemen biaya. 


\section{Perhitungan Harga Pokok Produksi Epiacollection}

Berdasarkan hasil penelitian, untuk memproduksi buket dibutuhkan biaya bahan baku, biaya tenaga kerja langsung dan biaya overhead pabrik, meliputi:

a. Bahan baku: kain satin, kawat tangkai, kain pembungkus dan flanel.

b. Biaya tenaga kerja langsung adalah biaya yang dikeluarkan untuk mmembayar tenaga kerja yang berperan dalam proses produksi. Biaya tenaga kerja langsung disini adalah biaya karyawan menjahit kain menjadi bunga.

c. Biaya overhead pabrik meliputi biaya overhead pabrik tetap, dan biaya overhead pabrik variabel. BOP Tetap dalam proses ini ada pita satin, lem tembak, kawat tangkai, kain pembungkus, plastik lembaran. Sedangkan BOP Variabelnya ada listrik untuk menjahit dan biaya akomodasi untuk COD dengan pembeli.

Berikut ini merupakan perbandingan perhitungan komponen harga pokok produksi menggunakan metode full costing dan metode variabel costing untuk memproduksi sepuluh unit buket bunga:

\section{Tabel 4.2}

Perhitungan Komponen Harga Pokok Produksi Epiacollection

\begin{tabular}{|c|c|c|c|c|}
\hline Komponen Biaya & \multicolumn{2}{|c|}{$\begin{array}{l}\text { Metode Full } \\
\text { Costing }\end{array}$} & \multicolumn{2}{|c|}{$\begin{array}{c}\text { Metode Variable } \\
\text { Costing }\end{array}$} \\
\hline \multicolumn{5}{|l|}{ Biaya Bahan Baku } \\
\hline Kain Satin & $\mathrm{Rp}$ & 60.000 & $\mathrm{Rp}$ & 60.000 \\
\hline Kawat tangkai & $\mathrm{Rp}$ & 25.000 & $\mathrm{Rp}$ & 25.000 \\
\hline Kain pembungkus & $\mathrm{Rp}$ & 15.000 & $\mathrm{Rp}$ & 15.000 \\
\hline Flanel & $\mathrm{Rp}$ & 80.000 & $\mathrm{Rp}$ & 80.000 \\
\hline \multicolumn{5}{|l|}{ Biaya Tenaga Kerja } \\
\hline Penjahit & $\mathrm{Rp}$ & 50.000 & $\mathrm{Rp}$ & 50.000 \\
\hline \multicolumn{5}{|l|}{$\begin{array}{l}\text { Biaya Overhead } \\
\text { Pabrik }\end{array}$} \\
\hline \multicolumn{5}{|l|}{ BOP Tetap: } \\
\hline Pita Satin & $\mathrm{Rp}$ & 7.500 & & \\
\hline Lem tembak & $\mathrm{Rp}$ & 20.000 & & \\
\hline Plastik & $\mathrm{Rp}$ & 13.000 & & \\
\hline \multicolumn{5}{|l|}{ BOP Variabel: } \\
\hline Listrik untuk produksi & $\mathrm{Rp}$ & 50.000 & $\mathrm{Rp}$ & 50.000 \\
\hline Biaya akomodasi & $\mathrm{Rp}$ & 30.000 & $\mathrm{Rp}$ & 30.000 \\
\hline Total HPP & $\mathbf{R p}$ & 350.500 & $\mathbf{R p}$ & 280.000 \\
\hline HPP /Unit & $\mathrm{Rp}$ & 35.050 & $\mathrm{Rp}$ & 28.000 \\
\hline
\end{tabular}

Sumber: Data Primer diolah tahun 2018

Berdasarkan hasil perhitungan pada tabel 4.2 di atas terdapat perbedaan Harga Pokok Produksi sofa antara metode full costing dengan metode variable costing, selisihnya sebesar Rp 7.050/unit. Perhitungan Harga Pokok Produksi pada Epiacollection merupakan perhitungan untuk 10 unit buket bunga flanel.

\section{Perhitungan Harga Pokok Produksi Kaafah}

\section{Collection}

Kaaffah Collection merupakan usaha yang memproduksi beberapa macam produk seperti bros, gelang dan kalung etnik. Berikut 
merupakan perhitungan harga pokok produksi untuk memproduksi bros. Berdasarkan hasil penelitian untuk memproduksi bros dibutuhkan biaya bahan baku, biaya tenaga kerja langsung dan biaya overhead pabrik, meliputi:

a. Bahan baku: mutsin jeruk, jarum bros.

b. Biaya tenaga kerja langsung adalah biaya yang dikeluarkan untuk mmembayar tenaga kerja yang berperan dalam proses produksi. Biaya tenaga kerja langsung disini adalah biaya karyawan pembuat bros.

c. Biaya overhead pabrik meliputi biaya overhead pabrik tetap, dan biaya overhead pabrik variabel. BOP Tetap dalam proses ini adalah biaya packing. Sedangkan BOP Variabelnya ada biaya promosi.

Berikut ini merupakan perbandingan perhitungan komponen harga pokok produksi menggunakan metode full costing dan metode variabel costing untuk memproduksi sepuluh unit bros:

\section{Tabel 4.3}

Perhitungan Komponen Harga Pokok Produksi Kaaffah Collection

\begin{tabular}{|l|l|l|}
\hline Komponen Biaya & \multicolumn{1}{|c|}{$\begin{array}{c}\text { Metode Full } \\
\text { Costing }\end{array}$} & $\begin{array}{c}\text { Metode Variable } \\
\text { Costing }\end{array}$ \\
\hline Biaya Bahan Baku & & \\
\hline Mutsin Jeruk & $\mathrm{Rp} \quad 50.000$ & $\mathrm{Rp}$ \\
\hline
\end{tabular}

\begin{tabular}{|c|c|c|c|c|}
\hline Komponen Biaya & \multicolumn{2}{|c|}{$\begin{array}{l}\text { Metode Full } \\
\text { Cocting }\end{array}$} & \multicolumn{2}{|c|}{$\begin{array}{c}\text { Metode Variable } \\
\text { Coctino }\end{array}$} \\
\hline Jarum Bros & $\mathrm{Rp}$ & 50.000 & $\mathrm{Rp}$ & 50.000 \\
\hline \multicolumn{5}{|l|}{ Biaya Tenaga Kerja } \\
\hline Tenaga Kerja & $\mathrm{Rp}$ & 50.000 & $\mathrm{Rp}$ & 50.000 \\
\hline \multicolumn{5}{|l|}{$\begin{array}{l}\text { Biaya Overhead } \\
\text { Pabrik }\end{array}$} \\
\hline \multicolumn{5}{|l|}{ BOP Tetap: } \\
\hline Packing & $\mathrm{Rp}$ & 20.000 & & \\
\hline \multicolumn{5}{|l|}{ BOP Variabel: } \\
\hline Promosi & $\mathrm{Rp}$ & 30.000 & $\mathrm{Rp}$ & 30.000 \\
\hline Total HPP & $\mathbf{R p}$ & 200.000 & Rp & 180.000 \\
\hline HPP/Unit & $\mathbf{R p}$ & 6.667 & $\mathbf{R p}$ & 6.000 \\
\hline
\end{tabular}

Sumber: Data Primer diolah tahun 2018

Berdasarkan hasil perhitungan pada tabel 4.3 di atas terdapat perbedaan Harga Pokok Produksi sofa antara metode full costing dengan metode variable costing, selisihnya sebesar Rp 667/unit. Perhitungan Harga Pokok Produksi pada Epiacollection merupakan perhitungan untuk 10 unit bros.

\section{Perhitungan Harga Pokok Produksi Kripik} Pisang Ibu Sri Hastuti

Berdasarkan hasil penelitian untuk memproduksi keripik pisang dibutuhkan biaya bahan baku, biaya tenaga kerja langsung dan biaya overhead pabrik, meliputi:

a. Bahan baku: pisang, bumbu, minyak

b. Biaya tenaga kerja langsung adalah biaya yang dikeluarkan untuk mmembayar tenaga kerja yang berperan dalam proses produksi. Biaya tenaga kerja langsung disini adalah biaya karyawan pembuat kripik. 
c. Biaya overhead pabrik meliputi biaya overhead pabrik tetap, dan biaya overhead pabrik variabel. BOP Tetap dalam proses ini adalah biaya packing. Sedangkan BOP Variabelnya ada biaya promosi dan gas.

Berikut ini merupakan perbandingan perhitungan komponen harga pokok produksi 25 Kilogram $(\mathrm{Kg})$ keripik singkong:

\section{Tabel 4.4}

Perhitungan Komponen Harga Pokok Produksi Kripik Pisang Ibu Sri Hastuti:

\begin{tabular}{|c|c|c|c|c|}
\hline Komponen Biaya & \multicolumn{2}{|c|}{$\begin{array}{l}\text { Metode Full } \\
\text { Costing }\end{array}$} & \multicolumn{2}{|c|}{$\begin{array}{c}\text { Metode Variable } \\
\text { Costing }\end{array}$} \\
\hline \multicolumn{5}{|l|}{ Biaya Bahan Baku } \\
\hline Pisang & $\mathrm{Rp}$ & 350.000 & $\mathrm{Rp}$ & 350.000 \\
\hline Bumbu & $\mathrm{Rp}$ & 25.000 & $\mathrm{Rp}$ & 25.000 \\
\hline Minyak & $\mathrm{Rp}$ & 180.000 & $\mathrm{Rp}$ & 180.000 \\
\hline \multicolumn{5}{|l|}{ Biaya Tenaga Kerja } \\
\hline Tenaga Kerja & $\mathrm{Rp}$ & 100.000 & $\mathrm{Rp}$ & 100.000 \\
\hline \multicolumn{5}{|l|}{$\begin{array}{l}\text { Biaya Overhead } \\
\text { Pabrik }\end{array}$} \\
\hline \multicolumn{5}{|l|}{ BOP Tetap: } \\
\hline Packing & $\mathrm{Rp}$ & 15.000 & & \\
\hline \multicolumn{5}{|l|}{ BOP Variabel: } \\
\hline Promosi & $\mathrm{Rp}$ & 30.000 & $\mathrm{Rp}$ & 30.000 \\
\hline Gas & $\mathrm{Rp}$ & 30.000 & $\mathrm{Rp}$ & 30.000 \\
\hline Total HPP & $\mathbf{R p}$ & 700.000 & $\mathbf{R p}$ & 685.000 \\
\hline HPP/kg & $\mathbf{R p}$ & 28.000 & $\mathbf{R p}$ & 27.400 \\
\hline
\end{tabular}

Sumber: Data Primer diolah tahun 2018

Berdasarkan hasil perhitungan pada tabel 4.4 di atas terdapat perbedaan Harga Pokok Produksi kripikpisang antara metode full costing dengan metode variable costing, selisihnya sebesar Rp 600/Kg. Perhitungan
Harga Pokok Produksi pada kripik pisang merupakan perhitungan untuk $25 \mathrm{Kg}$ kripik pisang.

Berdasarkan hasil penelitian pelaku UMKM memiliki kesulitan dalam mengidentifikasi biaya produksi sehingga selama ini belum dilakukan perhitungan harga pokok produksi. Penentuan harga jual yang dilakukan oleh para pelaku UMKM selama ini masih atas dasar perkiraan biaya yang dikeluarkan untuk memprodukasi dan membandingkan dengan harga pasaran produk serupa. Metode variabel costing memiliki kelebihan dalam pembebanan biaya namun dalam praktiknya pelaku UMKM kesulitan untuk menerapkan metode variabel costing, selain itu jika para pelaku UMKM menggunakan metode variabel costing maka ada beberapa elemen biaya yang tidak diperhitungkan jika dasar penentuan harga jualnya adalah dengan perhitungan harga pokok produksi.

\section{SIMPULAN}

Tujuan dilakukannya penelitian ini adalah untuk mengetahui metode penentuan harga produksi yang dapat digunakan sebagai dasar penentuan harga jual produk oleh para pelaku UMKM khususnya di daerah Tegal. Dari hasil penelitian dapat disimpulkan bahwa 
umumnya para pelaku UMKM belum menghitung harga pokok produksi secara terperinci yaitu masing menggunakan dasar perkiraan. Hasil penelitian juga menunjukkan bahwa metode perhitungan full costing lebih mudah dipahami oleh para pelaku UMKM dibandingkan metode variabel costing, dan apabila dasar penentuan harga jualnya hanya dengan memperhitungkan harga pokok produksi maka metode variabel costing lebih tepat digunakkan. Apabila para pelaku UMKM memperhitungkan harga pokok produksinya dengan metode variabel costing maka ada beberapa elemen biaya yang tidak diperhitungkan dan ini akan berdampak pada penentuan harga jual yang lebih rendah. Jika penentuan harga jual lebih rendah maka akan berdampak pada keuntungan yang diperoleh oleh para pelaku UMKM.

Saran yang dapat diberikan dari hasil penelitian ini untuk penelitian selanjutnya adalah: Para pemilik usaha sebaiknya memperhitungkan harga pokok produksi sehingga memiliki dasar dalam menentukan harga jual. Dengan memperhitunkan harga pokok produksi secara rinci maka dapat memprediksikan keuntungan yang diinginkan oleh pemilik usaha.

\section{DAFTAR PUSTAKA}

Mulyadi. 2007. Akuntansi Biaya. Yogyakarta: BPFE-UGM

Hansen, R dan Mowen.2005. Akuntansi Manajemen. Jakarta: Salemba Empat.

Sukirno, S. 2006. Ekonomi Pembangunan proses, masalah dan kebijakan. Kencana: Jakarta.

Sugiyono. 2014. Metode Penelitian Kuantitatif, Kualitatif dan R\&D. Bandung: Alfabeta 